\title{
The Transnational in the Local: The Larzac plateau as a site of transnational activism since 1970
}

\section{Robert Gildea and Andrew Tompkins}

Abstract. This article explores the case of the Larzac plateau in southern France which was the site of protests against the extension of a military base in the 1970s. It analyses the development of the site as a focus of local, national and transnational protest, drawing in post-1968 gauchistes in France and West Germany. After the cancellation of the military base the Larzac protest became a model for protest from Latin America to the Pacific against the threats of globalisation, which in turn transformed local protest. The limits of transnationalism were nevertheless demonstrated by contested understandings of the Larzac model of non-violent protest by activists from different contexts with their own agendas.

Keywords: 1968, gauchistes, non-violence, peasant activism, anti-nuclear, antiglobalisation, glocal, France, West Germany

On 28 October 1971 French Defence Minister Michel Debré announced plans for the extension of a military camp on the Larzac plateau in the Causses region of the Southern Massif Central from 3000 to 17000 hectares, which threatened to expropriate scores of sheep farmers. He attempted to minimise the impact by arguing that the plateau was almost deserted and that the peasants who inhabited it had scarcely changed their mode of existence since the Middle Ages. This announcement nevertheless provoked a ten-year campaign, not only of local farmers but also of outside activists who rallied to the cause from all over the region, country and across Europe and beyond. ${ }^{1}$ Initial tensions between Catholic farmers and Marxist activists were reduced by mutually transformative learning processes about the changing nature of revolution, the importance of local struggles, internal colonisation and ecology. The Larzac struggle became a model for other protests, although what it

\footnotetext{
${ }^{1}$ On the Larzac struggle see Michel Le Bris, Les Fous du Larzac (Paris, Les Presses d'aujourd'hui, 1975); Jeannette Colombel, 'Résistance du Larzac, 1971-1977', Les Temps modernes 371 (June 1977), 1971-2088; Didier Martin, Larzac. Utopies et Realités (Paris, L'Harmattan, 1987); Alexandre Alland, Le Larzac et après. L'Étude d'un mouvement social novateur (Paris, L'Harmattan, 1995); Roger Rawlinson, Larzac. A nonviolent campaign of the '70s in southern France (York, William Sessions, 1996); Pauline Vuarin, 'Larzac 1971-1981: La Dynamique des Acteurs d'une Lutte Originale et Créatrice' (mémoire de maîtrise, Paris 1 Panthéon-Sorbone, 2005); Pierre-Marie Terral, Larzac: de la Lutte paysanne à l'Altermondialisme (Toulouse, 2011); Christiane Burguière, Gardarem! Chronique du Larzac en lutte (Toulouse, Privat, 2011).
} 
entailed was subject to different interpretations and local conditions. The campaign ended in success when the government of François Mitterrand, elected in 1981, abandoned plans to extend the base. The Larzac then became a base for a 'return of solidarity' whereby the local activist community reached out to movements from Latin America to the Pacific Islands that were resisting late colonialism, American imperialism and relentless global capitalism. It also brought these struggles home to support the Larzac's local struggles in the 1990s against the global threat of the World Trade Organisation.

The case of the Larzac demonstrates in an exemplary manner how a very local struggle became a transnational one, situated within concentric regional, national and global networks of protest. By 'transnational' here we understand a struggle in which protesters not only moved across national borders, but underwent significant change in the process, modifying their outlook, strategies, protest practices and personal trajectories as a result. ${ }^{2}$ The Larzac farmers experienced transformative transnational encounters not just with exotic people in distant places like the South Pacific, but also with European neighbours. ${ }^{3}$ Local farmers exposed to outside campaigners became more cosmopolitan, open-minded and ready to contribute to wider struggles. This did not mean that the encounters were easy, nor that there was not ample opportunity for tension and conflict between activists of different origins; it is thus the limitations as well as the successes of transnational activism which are under consideration here. ${ }^{4}$ The Larzac case also offers a contribution to the debate about 'glocalisation'. ${ }^{5}$ It demonstrated that global and local were not necessarily antithetical but could actually be complementary, that local campaigns could mutate into global ones and global

\footnotetext{
${ }^{2}$ See Robert Gildea, James Mark and Anette Warring eds., Europe's 1968. Voices of Revolt (Oxford: Oxford University Press, 2013) and Andrew Tompkins, "Better Active Today than Radioactive Tomorrow!": Transnational Opposition to Nuclear Energy in France and West Germany, 1968-1981' (DPhil thesis, University of Oxford, 2013). See also Xavier Vigna and Michelle Zancarini-Fournel, 'Les rencontres improbables dans « les années 68 »', Vingtième siècle 101 (2009), 163-77 and Michel Werner and Bénédicte Zimmermann, 'Beyond Comparison: Histoire croisée and the challenge of Reflexivity', Theory and History 45 (2006), 30-50 for more on the transformative function of encounters (national and transnational).

${ }^{3}$ On the importance of examining transnational connections within and beyond Europe, see Patricia Clavin, 'Time, Manner, Place: Writing Modern European History in Global, Transnational and International Contexts', European History Quarterly 40 (2010), 624-40.

${ }^{4}$ On the complexities of transnational communication for social movements, see H. Nehring, 'National Internationalists: British and West German Protests against Nuclear Weapons, the Politics of Transnational Communications and the Social History of the Cold War, 1957-1964', Contemporary European History, 14, 4 (2005), 559-582.

${ }^{5}$ Roland Robertson, 'Globalisation or glocalisation?', The Journal of International Communication 1:1 (1994), 33-52, reprinted in 18:2 (2012), 191-208; Victor Roudmetof, 'Transnationalism, Cosmopolitanism and Glocalisation', Current Sociology 53:1 (2005), 113-35.
} 
ones be undertaken on a local basis. Over the years the Larzac became the mainspring and also showcase of transnational struggles, open to the strife of the world but also powerfully wedded to its local identity.

For Michel Debré the Larzac struggle was a rearguard action of a backward peasantry resisting the inevitable forces of economic progress, state-building and great-power advancement. He thereby misunderstood not only the farmers of the plateau, but also the ways in which the 'rural revolution' of the 1950s and 1960s had linked agriculture to wider markets and new methods - and thus also to new organisations and forms of protest. ${ }^{6}$ The Larzac seemed isolated but the plateau's sheep farmers, half of whom owned land and half of whom were tenants (on farms averaging 28 hectares), worked in joint professional organisations with industrialists for the production of Roquefort cheese. In 1971 some 90,000 sheep grazed on the plateau and produced 2.3 million litres of milk; $21 \%$ of the flock, $47 \%$ of the milk and 108 farms were threatened by the planned extension. ${ }^{7}$ True, there were farming families such as the Jonquet, the Guiraud and the Maillé, known as the 'purs porcs', who had lived and worked on the plateau for as long as anyone could remember. However, there were also more recent arrivals who came with new ideas. Léon Burguière had come to plateau in 1952 from the other end of the Aveyron department. His two sons, Jean-Marie (b.1938) and Pierre (b. 1943), married two sisters respectively in 1962 and 1965, and in 1970 he retired and gave his farm over to his sons and daughters-in-law who formed a Groupement agricole d'exploitation en commun (GAEC). Jean-Marie and Pierre had been members of the Jeunesse Agricole Chrétienne (JAC) which, under the eye of the clergy, confronted young farmers who had left school with the challenges of the modern world, created networks which stretched across France and trained activists who would become involved in agricultural unions. Finally, there were others with a military rather than a peasant background, who came from parts of the French Empire as decolonisation took its course and had been on the plateau only a few years. Guy Tarlier came from a bourgeois family in Bapaume (Pas-de-Calais), was educated by the Jesuits and joined the army, but refused to fight in the Indochinese war and was posted to Brazzaville.

\footnotetext{
${ }^{6}$ Gordon Wright, Rural Revolution in France. The Peasantry in the Twentieth Century (Stanford, Stanford UP, 1964), 143-82; Henri Mendras, The Vanishing Peasant. Innovation and Change in French Africulture (Camb. Mass \& London, MIT Press, 1970).

${ }^{7}$ Rawlinson, Larzac, 16-19.
} 
He left the army as a captain but stayed on with his wife Marizette (b. 1932) as a coffee planter in the Central African Republic for a time after it obtained independence, coming to the Larzac in 1965. Marizette admits that 'we were a little African' and were regarded as colonists and intruders when they arrived, but Guy was at the forefront of technological developments, perfecting a mechanical milking machine for sheep in 1971. He also emerged as a key organiser of the struggle, although he rarely spoke in public because he had neither the appearance nor the language of a local farmer. ${ }^{8}$

The success of the Larzac campaign depended on the sheep farmers cooperating with outsiders who had more organisational power and experience, although solidarity was not initially easy to establish. The first organisation set up by farmers and local notables in January 1971, as rumours began to spread, was the Association de sauvegarde du Larzac, which hoped to dialogue with a government which had already made up its mind. A first demonstration in the local town of Millau on 9 May 1971 was inspired by Robert Siméon, a Paris printer who had been imprisoned in 1962-4 for his refusal to fight in the Algerian War and his work with draft-dodgers and deserters. Retraining as a shepherd, he came to the Larzac in 1968 and organised the march with the Parti Socialiste Unifié (PSU), which had broken with the Socialist Party (SFIO) over the latter's support for the Algerian war, and the Mouvement pour le Désarmement, la Paix et la Liberté (MDPL), France's version of CND. The march was joined by gauchistes of various kinds, some of whom had come on 'long marches' to the countryside that were modelled on Mao's revolution in China. ${ }^{9}$ This rather 'urban', left-wing march was, however, boycotted by suspicious sheep farmers, apart from the Tarliers. ${ }^{10}$

Attacks by unidentified left-wingers on government and Gaullist buildings in Millau and Rodez in February and March 1972 sent out a warning that the defence of the plateau might fall into the hands of uncontrollable and potentially violent outsiders. ${ }^{11}$ The sheep farmers were themselves mobilised through the intervention of Lanza del Vasto, a charismatic outsider who was more to their taste. A Sicilian noble by origin, he was an exotic, "biblical' 12 figure in his long beard and homespun cotton

\footnotetext{
${ }^{8}$ Interview with Marizette Tarlier, recorded by RG, Creissels, 22 May 2008.

${ }^{9}$ Le Bris, op. cit., 154-167; Alland, op. cit., 159.

${ }^{10}$ Interview with Robert Siméon, recorded by RG, Millau, 20 May 2008.

${ }^{11}$ Terral, Larzac, 53-4.

12 Yves Hardy and Emmanuel Gaby, L...Comme Larzac (Paris, Alain Moreau, 1974), 76.
} 
robes, who had met Gandhi in 1937 and saw himself as Gandhi's disciple in the West. Lanza was in fact no stranger to the Larzac. His Arche community (founded in 1948, based on the Gandhian ashram and dedicated to the philosophy of non-violence) had its headquarters at La Borie Noble (Hérault) fifty kilometers away. His Compagnons had campaigned against the atomic bomb since 1958, come on a pilgrimage to the Larzac in 1959 to criticise its use as an internment camp for 'suspected' Algerian rebels, and joined the campaign against the French army's use of torture against Algerians. Robert Siméon, who knew Lanza from his campaigning against the Algerian War, was instrumental in bringing him to mobilise the sheep farmers through a fortnight-long fast over Easter 1972. This culminated in an oath taken on 28 March 1972, when 103 of the 109 sheep farmers who were threatened with expropriation swore that they would act collectively, surrendering neither to intimidation nor offers of money for their land, until the plateau was safe from the military. ${ }^{13}$ The sheep farmers were transformed from mutually suspicious individuals into a united force dedicated to a struggle that would do everything to remain nonviolent. Guy Tarlier recalled that

Lanza del Vasto was the cement of our union, because at the start we were very different in our upbringings and ways of seeing agriculture. There were quarrels about hedges and sheep that went missing on the neighbour's meadow. All that was swept away by Lanza. He was the catalyst... I have a strong personality and for me they were bleating pacifists, as you might say. To become non-violent requires a lot of self-discipline, reasoning, moral strength. It's more than a technique, it's a state of mind. But if we had used violence we would have lost the game a long time ago. ${ }^{14}$

Pierre and Christiane (b. 1946) Burguière, who were among the 103 farmers, described the charisma of Lanza and the force of his argument that the only viable way to confront the military state was by non-violent resistance:

$\mathrm{CB}$ : He conquered his audience completely because we felt carried, supported by someone. He was like a beacon in fact... because we were completely in the dark and suddenly he told us what we had to do....

PB: He told us something: 'In any case you don't have weapons and you are going to find yourself up against a power that will crush you'.... He said, 'think of doing things that will take public opinion with you.' Very soon we

\footnotetext{
${ }^{13}$ Lanza del Vasto, Technique de la Non-Violence (Paris, Denoël, 1971), 55-66, 97-114, 237-9; Jean Toulat, Combattants de la non-violence. De Lanza del Vasto au Général de la Bollardière (Paris, Cerf, 1983), 24-55, 67-81, 104-9.

${ }^{14}$ Cited by Toulat, Combattants de la non-violence, 109.
} 
discovered that non-violence is an extraordinary defence technique. We simply had to understand it and adapt it to our struggle. ${ }^{15}$

Lanza del Vasto had preached his message of non-violence far and wide over the years, meeting with various degrees of success. His Larzac intervention counts as one of the most successful; others, such as his fasts to oppose a nuclear power plant in Creys-Malville or a chemical processing plant in Marckolsheim, were of only fleeting importance. ${ }^{16}$ Younger and more left-wing protesters found him insufferably religious, full of false modesty and self-righteousness. ${ }^{17}$ However, his message fell on exceptionally fertile ground on the Larzac in no small part because of the strong Christian faith of the Aveyron. The vast majority of the community were practising Catholics. Jean-Marie and Pierre Burguière had both attended seminary and were members of the JAC; Jean-Marie had indeed considered a career in the priesthood. They also developed their Christian commitment as a way of legitimising their struggle as one inspired by a thirst for justice and fraternity. ${ }^{18}$ Christiane and Pierre Burguière recalled,

CB: We had faith. We were able to win because of the faith we had during the struggle.... Faith in man, faith in life, faith in God, yes... The faith we had during the struggle helped us to win.... We believed, otherwise we would never have battled... We would have given up from the start.

PB: We put ourselves in the hands of God, it's true, it may sound a bit $\mathrm{CB}$ : And we always said, 'our cause is just'. ${ }^{19}$

Christianity may explain the sheep farmers' faith in their cause, but it cannot explain the force of their opposition to the state. In retrospect, some of this went back to the Algerian War on their side too. Jean-Marie Burguière has reasserted his pre1968 opposition to the government by explaining how his stubborn opposition to the Algerian War got him off the draft. As a seminarist he was exempted from military service until he finished his studies, but friends who had gone to Algeria told him about the French army's torture of Algerian rebels. He told the recruiting officer,

\footnotetext{
${ }^{15}$ Interview with Pierre and Christiane Burguière, conducted by RG, Le Camper du Larzac, 22 May 2008

16 'Interview zur Entwicklung der gewaltfreien Bewegung im Elsass (vermutlich 1975)', transcript in Archiv Aktiv, Hamburg, 'Ökologiebewegung im Elsass' folder; Pièces et main d'oeuvre (PMO), 'Memento Malville. Une histoire des années soixante-dix', (2005) [http://www.piecesetmaindoeuvre.com/spip.php?article1] (accessed 1 Nov. 2012).

${ }^{17}$ Hardy and Gabey, op. cit., 76-79.

18 'Au Larzac, des Chrétiens ont pris conscience', Notre Combat 101 (Dec. 1977-Jan. 1978), 9-13. Interview with Pierre, Christiane and Janine Burguière.

${ }^{19}$ Pierre and Christiane Burguière interview.
} 
I am warning you, I will join the fellaghas. I know what is happening in Algeria.' We talked for two hours at least. Then he corrected what he had written and said, 'Right. RD2. Unfit for service, no pension'. And I went home. At a time when nobody was being discharged. ${ }^{20}$

The Algerian War also shaped the thinking of farmers from other parts of France, such as Bernard Lambert (1931-84). Lambert, a share-cropper's son from Brittany, like the Burguières the product of Catholic education and youth activism in the JAC, had made his political reputation through opposition to the Algerian War, first in 1956 as a reluctant conscript, then attacking it when he was elected a young deputy for the Catholic Mouvement Républician Populaire (MRP) in 1958. Too radical for the MRP he lost his seat in 1962 and joined the Parti Socialiste Unifié (PSU). He linked up with the Larzac farmers in January 1973 when they mounted a media coup by setting out in a tractor convoy for Paris. Stopped by the police at Orléans they were helped by Bernard Lambert and his Paysans-Travailleurs trade union, which mobilised tractors from supporters in the Loiret so that they could complete the final leg to Paris. ${ }^{21}$ Actions like these attracted national attention to the Larzac farmers' cause.

With national attention came a growing network of outside supporters, which included many former gauchistes of May 1968. At the outset and for some time the farmers felt only incomprehension and disgust towards soixante-huitards.

Overwhelmingly Catholic and conservative, they had little patience with urban youth who they saw as sexually promiscuous and violent 'casseurs'. And yet within two or three years the farmers found themselves making common cause with these outside agitators. On the question of cooperation Jean-Marie Burguière recalls:

We were very strongly against it. I was very strongly against it. I said, 'They are layabouts. They only think about having sex'. My father spoke to me about it. For him it was shocking. We said, 'It's disgusting', because we were very modest. We were shocked. Then the story of the Larzac came along and we had lots of contact with what were called gauchistes.... When someone asked my father, 'You, Monsieur Burguière, after all, when you see all these gauchistes, all these hippies, what do you think?' And my father answered, 'I don't look at the colour of the hand that is held out to me'. He was right. Unfortunately - no, fortunately - it was people like that who saved us. Those people - not rightwing people, in general. ${ }^{22}$

\footnotetext{
${ }^{20}$ Interview with Jean-Marie Burguière, conducted by RG, La Ferme de l'Hôpital, 21 May 2008. Marcel Bigeard (1916-2010) was a parachute regiment commander and key player in the 1957 Battle of Algiers.

${ }^{21}$ Yves Chavagne, Bernard Lambert. Trente ans de combat (Quimperlé, La Digitale, 1988).

22 Jean-Marie Burguière interview.
} 
For his younger brother Pierre it was confrontation with the state and its lies that caused his change of thinking. Whereas in 1968 he had cheered for law and order while watching police attack gauchistes on television, he and his community now came up against the reality of state violence and propaganda.

In May 68 there was a certain press, we read a certain press, we watched the television. To be honest we did not read left-wing papers... Nothing happened in Millau and at the beginning of the Larzac struggle, when we saw how the media reported the Larzac and what we were doing, we said, 'But they were lying to us, they were lying to us the whole time... When Debré talked about the Larzac he said that the crows took a backpack to cross the Larzac, that it was a desert, a French Siberia. That was a tissue of lies because as he said that there were a number of young farmers who were setting up there. There was an agricultural revival. ${ }^{23}$

In this conversion of the farmers to a wider struggle against the state, Bernard Lambert played a pivotal role. In May 1968 he orchestrated a united demonstration of farmers, workers and students in Nantes and the Cahiers de mai presented him as 'the new revolutionary conscience of the peasantry'. ${ }^{24}$ In 1970 he published Les Paysans dans la lutte de classes (with a preface by PSU leader Michel Rocard), which argued that the modernisation of agriculture had in fact proletarianised farmers as industrial food companies monopolised supplies of fertiliser and foodstuffs, squeezing prices and controlling all outlets. ${ }^{25}$ In it, he reflected on possibilities for co-operation with student radicals that would preserve the authority of the farmers.

Explanation and contact [with students] are necessary. Their participation in farm work, their presence in grassroots meetings is desirable and useful. Often, the students who are the sons of peasants and workers are the best prepared, but that does not exclude the others. [But] If the students seek, via such contact, to teach peasants the brand new theories they've just discovered in order to direct the popular struggle of the masses, they would do better to stay at home. ${ }^{26}$

For their part the gauchistes of 1968 had also learned a great deal about the nature of revolution and social change. Most had been fully committed to Marxism and its various strands of Trotskyism or Maoism. They had believed in class war and proletarian revolution that would take the form of the Paris Commune or the

\footnotetext{
${ }^{23}$ Pierre and Christiane Burguière interview.

${ }^{24}$ Cahiers de mai I (15 June, 1968), 10.

25 Bernard Lambert, Les Paysans dans la Lutte des classes (Paris, Seuil, 1970). See also 'Quand un paysan devient marxiste', Esprit 4/5 (April-May 1977), 70-5; and Recueil de textes choisis (19551984) (Association Bernard Lambert, 1985).

${ }^{26}$ Lambert, Les Paysans dans la lutte des classes, 160.
} 
Bolshevik seizure of power in 1917, along the lines of 'Ten Days that Shook the World'. However the state regained control of the streets from the student movement and dissolved leading Marxist organisations. The mass strikes of May-June 1968 never returned and attempts by Maoists to work incognito in factories to stir up the workers failed to fulfil their lofty ambitions. By the early 1970s, the left was undergoing a fundamental transformation. Many Marxist activists re-conceived revolution not as a challenge to state power at its centre but as a series of decentralised struggles and prolonged campaigns that would establish autonomy on a local basis. For example, Benny Lévy, leader of the Maoist Gauche Prolétarienne, told Jean-Paul Sartre in 1974 that 'the most important thing is to gain experience in a partial, local, even in part symbolic, taking of power'. ${ }^{27}$

These ideas converged with the thinking of other left-leaning contemporaries such as hippies, neo-ruralists and écologistes, who likewise valued decentralisation and autonomy. During the 1970s, such activists established communes in the countryside as part of a 'return to the land', in which they sought 'marginal' and 'authentic' spaces outside the orbit of modern consumer society. ${ }^{28}$ The shift from class to community and the cult of the local struggle was common across Europe, including for the activists of Turin-based Lotta Continua, whose philosophy was to move beyond the factory to 'take the city' as a whole'. ${ }^{29}$ As Hélène Hatzfeld has written, 'The 1960s-1970s "invent[ed]" the local, anchoring it on the left' and thereby enhancing the appeal of local, rural struggles like the Larzac. ${ }^{30}$

Furthermore, while in the 1960s Marxist activists had been inspired by the struggles in the Third World against colonialism and American imperialism (symbolised by Castro's Cuba, Che's Bolivia, Ho Chi Minh's Vietnam and Mao’s Cultural Revolution), in the 1970s they came to believe that peripheral parts of Europe were also being 'colonised' by the more advanced industrial regions in the core of the European Community. While investment was pouring into the industrial regions the peripheral areas were being depopulated, pillaged, dumped upon, run by 'foreign' bureaucrats and technocrats, used as playgrounds by tourists and as military

\footnotetext{
${ }^{27}$ P. Gavi, J-P Sartre, P. Victor, On a raison de se révolter (Paris, Gallimard, 1974), 254-5. ('Pierre Victor' was a pseudonym of Benny Lévy.)

${ }^{28}$ D. Léger and B. Hervieu, Le retour à la nature (Paris, Seuil, 1979).

${ }^{29}$ L. Bobbio, Lotta Continua. Storia di un'organizzazione rivoluzionaria (Roma, Savelli, 1979). See also Gildea, Mark and Warring eds., Europe's 1968, 123-9.

${ }^{30}$ See the chapter 'L'invention du local' in Hélène Hatzfeld, Faire de la politique autrement: Les expériences inachevées des années 1970 (Rennes, Presses Universitaires de Rennes, 2005), 181-190.
} 
bases by the army. The concept of 'internal colonisation' was developed to explain this development and enabled regionalism to shake off its reactionary, folkloric image and reinvent itself as the radical vehicle of justice and diversity. ${ }^{31}$ Occitanism became one of the symbols of the Larzac struggle, embraced both by local campaigners and by outsiders such as former Maoist Michel Le Bris, himself of Breton origin. ${ }^{32}$ Call for regional autonomy also gave the Larzac farmers ready allies elsewhere in France, in places like Alsace and Brittany.

Co-operation between sheep farmers and leftists developed not only at the level of discourse but on the ground, as they worked and learned together. One joint activity was the building of a new sheep shed which had no planning permission at La Blaquière, the farm of the 'pur porc' Auguste Guiraud. In fact it was less a shed than a Romanesque cathedral, the construction of which was directed from Whitsun 1973 by a Franciscan worker-priest, Robert Pirault. ${ }^{33}$ Hundreds of students and young people - a mix of 'Maoists, Catholics, scouts, schoolteachers and workers' ${ }^{34}$ - came from all over France and beyond, volunteering to work at La Blaquière and exchanging views with the local sheep farmers. The project was to become the model for further 'chantiers' in the late 1970s.

The union of farmers and gauchistes was dramatized by the "march to the Larzac' of 25-6 August 1973, centred at the Rajal del Guorp ('Crow Rock' in Occitan), that brought together $80-100,000$ people in a massive show of strength against the state. The event, masterminded by Bernard Lambert, symbolically united students, workers, and peasants. Thousands of young people swarmed the plateau, bare-chested or skimpily clad in the sun. 200 striking workers from the Lip watch factory came by coach from Besançon to proclaim the 'marriage of Lip and Larzac'. ${ }^{35}$ Referring to the soldiers of peasant origin who had crushed the Paris Commune in 1871, Bernard Lambert told the crowd, 'Never again will peasants be Versaillais!'36

\footnotetext{
${ }^{31}$ Robert Lafont, Décoloniser la France. Les regions face à l'Europe (Paris, Galliamrd, 1971); Robert Gildea, The Past in French History (New Haven, Yale, 1994), 188-9.

${ }^{32}$ Michel Le Bris, Occitanie: volem viure! (Paris, Gallimard, 1975); Robert Lafont, Pour l'Occitanie (Toulouse, Privat, 1979).

${ }^{33}$ On the worker-priest movement, see Oscar L. Arnal, Priests in Working-Class Blue: The History of the Worker-Priests (1943-1954) (New York, 1990) and Emile Poulat, Les Prêtres-ouvriers.Naissance et fin (Paris, 1999).

${ }^{34}$ Paul Ariès and Christian Terras, José Bové. La révolte d'un paysan (Villeurbanne, 2000), 12.

${ }^{35}$ Politique hebdo, 92 (30 Aug. 1973).

${ }^{36}$ This excerpt from Bernard Lambert's speech is included on the Larzac 73 LP, available at the Archiv der Sozialen Bewegungen in Baden (ASB), Freiburg, and in Christian Rouaud's film, Paysan et Rebelle (2002).
} 
The Larzac struggle was also presented as an episode in the struggle of the Occitan region against 'internal colonisation' by the industrial north and Jacobin centralized state by singers and theatre groups. ${ }^{37}$ Support was received from Irish republicans, not least because the Larzac plateau was used as a training ground by British troops who would be deployed in Northern Ireland, and the Croix Occitane exchanged flags with the Irish republican Starry Plough. ${ }^{38}$

Links between local farmers and campaigners from outside were developed through a network of Comités Larzac, in which gauchistes, pacifists, écologistes, and regionalists participated. One of the key movers in propagating Larzac committees was Pierre Vuarin (b. 1948). Brought up in Paris but hating school and bourgeois existence, he became an agriculture student, was involved in 'long marches' to rally support among the peasants of Brittany and Normandy in 1970-71, and was impressed by the China of the Cultural Revolution he visited in 1972. Taking a job with the Chambre d'Agriculture of the Aveyron at Rodez that autumn, he set up a Comité d'Action for the Larzac at Rodez, and joined an autonomous, Maoist faction of the PSU called the Gauche Ouvrière et Paysanne (GOP) which wanted to develop a 'peasant Left' on the Larzac. He recalls the closeness of the relationship formed with diverse groups of activists and with the peasant activists on the Larzac, while underlining that he himself belonged to an organisation dedicated to class struggle.

I threw myself with a huge amount of energy and for a fantastic time into involvement with the peasants, in particular on the Larzac.... We promoted Larzac committees nationally, with different kinds of people. There were nonviolent activists, Occitan nationalists, the GOP, anarchists but also Catholics in the Larzac committees - they were very open.... We lived together for ten years, we were closely tied, in a reasoned but friendly way. We respected each other, we did not attack each other, there was a deep friendship.... We [in the GOP] were personally not committed to non-violence. We argued that class confrontation and conflict existed, could not be denied, and might be an option. ${ }^{39}$

While welcoming this vital, outside support and meeting regularly with representatives of the Larzac committees, the farmers insisted that they should retain the final word on strategy and tactics, above all to keep to the chosen road of non-

\footnotetext{
${ }^{37}$ Le Bris, Occitanie, 143-5, 166-7. Recordings of the Occitan singers Marti and Patric are included on the aforementioned Larzac 73 and subsequent Larzac 74 LPs.

${ }^{38}$ A.W.M. Smith, 'The Comité Régional d'Action Viticole (CRAV): Regional identity, violence and the challenges of modernisation in the Languedoc, 1944-1992' (University of London PhD thesis, 2012), 212-14.

${ }^{39}$ Interview with Pierre Vuarin, conducted by RG, Paris, 12 May 2008
} 
violence. Pierre Burguière rehearses the argument for why they made non-violence and local control a condition of co-operation:

The committees came to see us and said, 'We should do this or that action next weekend'. And we said, 'That's fine, and you will be there on Monday, Tuesday and Wednesday to face the consequences of your action?' 'No, we have our jobs to go to'. 'Fine. From the moment you are ready to take the consequences we can work together because we have to live with the consequences every day'. ${ }^{40}$

Collaboration between locals and outsiders became more permanent as outsiders settled on the plateau and involved themselves in the struggle on a daily basis. Pierre-Yves de Boissieu (b. 1949) was a young shepherd who had been politicised by the events of 1968 (and thus an ideal intermediary between gauchistes and Larzaciens). He moved to the Larzac in September 1975 after years of searching throughout France for a farm where he and his family could settle; he was particularly frustrated when one farm he had been ready to buy in the Drôme was snatched up at the last minute by wealthy Dutch holidaymakers. Through the intervention of JeanMarie Burguière, who was trying to prevent abandoned farms on the plateau from being sold to the military, Pierre-Yves was finally able to settle on the Larzac, at the Les Homs farm. On account of his prior experiences, the Larzac struggle resonated personally with Pierre-Yves: 'I had been confronted with speculation in Drôme. There, it was tourists buying second homes, here it was the army, but it was the same thing - farms were disappearing. ${ }^{41}$ On the Larzac, Pierre-Yves found that protest became a regular part of his life.

I'd say it took two to three whole months out of a year, the presence in the struggle... That lasted ten years...Every week there was something... For example, while getting up in the morning to herd the sheep you'd notice out there in the distance these military trucks, jeeps and things like that... outside the military camp... And we 'created' an incident [by] preventing them from leaving. ${ }^{42}$

When the military could be surrounded outside the camp, Larzac residents would let the air out of jeep tyres, picnic in front of tanks, or go after army property with (pink) paint. Actions like these, which depended on a continuous local presence and vigilance on the ground, kept public attention focused on the Larzac struggle over the long term.

\footnotetext{
${ }^{40}$ Pierre and Christiane Burguière interview.

${ }^{41}$ Interview with Pierre-Yves de Boissieu, conducted by AST, Les Homs, Larzac, 15 September 2010.

42 Ibid.
} 
Another dimension of outside settlement was the 'squatterisation' of the plateau by conscientious objectors to military service who took refuge on the plateau. Whereas a previous generation of activists had gone to prison for refusing to serve in the Algerian War, the status of conscientious objector was finally extracted from the French government after the end of the war in 1963. That said, the status was made very difficult to obtain and required a longer term of civilian service as an alternative to military service. These conscientious objectors had wider horizons of activism than the farmers and more contacts with other (domestic and transnational) protest networks. They had to 'mix their labour' with the peasants by hay-making and harvesting (without pay), but soon agreed a new tactic with the farmers that would take the offensive into the army's camp: illegal occupation of land that had been sold to the army by landowners who were not part of the 103 oath-takers. Hervé Ott (b. 1949) saw his elder brother imprisoned in 1968 for refusing both military and civilian service and he himself founded a group of conscientious objectors when he was a theology student at Montpellier in 1969. He was an assistant Protestant pastor at Meyrueis in 1975 when he decided to join the Larzac struggle.

The first day I came to the Larzac I was told, 'there are houses owned by the army to occupy, empty houses to occupy. I said to myself, 'That's a project from heaven!' That's how I saw it at the time... I said, 'We need to create a group of conscientious objectors - of which there were a certain number on the Larzac with their own specific project... to occupy a farm. ${ }^{43}$

One member of Hervé Ott's group who occupied Le Cun in 1975 (and went on to occupy his own farm in 1976) was Christian Rocqueirol (b. 1954). His political awakening came with the 1973 coup against Allende in Chile and he became a Trotskyist, but faced by the obligation of military service in 1974 he became an anarchist and conscientious objector. Since he also refused to do the alternative civilian service, he effectively became an outlaw and came to the Larzac in 1975. With him came José Bové (b. 1953), whose parents had been researchers at the Institut National de la Recherche Agricole (INRA) and who had thus spent much of his childhood in Berkeley, California. In June 1976 all three were involved in a stunt in which farmers and conscientious objectors illegally entered the army camp in order to photograph documents detailing secret sales of land on the plateau to the army. Of the 22 protesters sent for trial, 17 went to prison. Following the intervention of the

\footnotetext{
${ }^{43}$ Interview with Hervé Ott, conducted by RG, Le Cun du Larzac, 24 May 2008.
} 
farming unions, farmers such as Pierre Burguière and Marizette Tarlier were released after a week or so to bring in the harvest. Ott, Rocqueirol and Bové served longer and as a result came to be considered fully-fledged members of the Larzac struggle. ${ }^{44}$

As the Larzac struggle grew, action took place not only on the plateau, but became decentralised. The Larzac committees were the instrument of a 'general mobilisation' that took place across France and beyond. ${ }^{45}$ One aspect of the campaign involved civil disobedience actions in which people far from the plateau could participate, such as sending military conscription papers back to the Defence Ministry or withholding $3 \%$ of one's taxes from the government and sending it to the Larzac instead. The committees also set up several Groupements de Financement Agricole (GFAs), which sold tiny parcels of land to raise funds from thousands of supporters and simultaneously complicate expropriation proceedings. In June 1974 the satirical weekly Le Canard enchaîné bought a plot of land that was duly equipped with a plastic-lined pond and bath duck. It also helped with the launch of the campaign's own paper, Gardarem lo Larzac, in $1975 .^{46}$

The general mobilisation undertaken by the Comités Larzac was, however, not restricted solely to the Larzac struggle but took the form of building solidarity with local protests elsewhere, according to the philosophy of taking power in multiple and symbolic ways. Where Che Guevara had called for 'Vietnams everywhere' the Larzac resisters called for 'des Larzac partout' ${ }^{47}$ Apart from the aforementioned 'marriage of Lip and Larzac' these alliances included campaigns against infrastructure projects such as military bases in Canjuers (Var) and Fontevraud (Maine-et-Loire); nuclear power stations in Braud-et-Saint-Louis (near Bordeaux), Creys-Malville (between Lyon and Geneva) and Plogoff (Brittany); a dam in Naussac (Lozère); and an airport in Vaumeilh (Alpes-de-Haute-Provence). Representatives from the Larzac travelled to and received visits from each of these (mostly rural) sites, exchanged ideas with their local counterparts (mostly farmers), mobilised their own protest networks for these other causes, and benefited substantially when their allies reciprocated. Collaboration was particularly successful with the residents of Plogoff, who established a GFA along the Larzac model. When they built a barn (illegally, i.e.

\footnotetext{
${ }^{44}$ Pauline Vuarin, 'Larzac 1971-1981', 63-71

${ }^{45}$ BNF Paris, 4-WZ-13 624, Recueil de tracts 'Larzac': 'Larzac: Mobilisation générale'

${ }^{46}$ Burguière, Gardarem!, 113-14, 157-60

${ }^{47}$ Comités Larzac, bulletin of 7 Aug. 1975, in AD Aveyron, Rodez, 747 W 8
} 
without planning permission) on the site, the Larzac farmers provided sheep with which to stock it; in return, the Larzac farmers were fêted as guests of honour at a rally of up to 150,000 in Plogoff in May 1980. The programme of 'Larzacs everywhere' that began in 1975 made the Larzac one of the central nodes in an expansive network of protest on behalf of multiple causes (see Figure 1).

<Insert FIGURE 1 with the following caption: "Figure 1. Map of selected national and transnational protest networks linked to the $\operatorname{Larzac}^{48 "}>$

While the Larzac provided an inspiring and widely imitated model of nonviolent struggle that brought local inhabitants together with outside activists, this was not always easy to replicate. According to Pierre-Yves de Boissieu, Larzac activists did not seek to directly transplant their own model to these other sites.

AST: Did you make suggestions [elsewhere] about specific things you had done here?

PYdB: It's difficult to make suggestions. We explain how we work. You can't say 'you must work like this' because the context elsewhere is different and because such-and-such a formula might not apply. So we always explained. We gave the three pillars of our struggle: physical resistance on the ground, resistance through the courts and an attack... [at the level of] land ownership. ${ }^{49}$

In fact, the stakes in the Larzac conflict were relatively low compared to those of other major projects. Though Valéry Giscard d'Estaing never abandoned his Gaullist predecessors' plans to expand the plateau's military base, his government placed a much greater priority on the construction of nuclear power plants. Nowhere was this truer than in Malville, where the Fast Breeder Reactor built starting in 1976 was conceived simultaneously as a paragon of French technology, the prototype for a lucrative export and a central element of the government's nuclear programme. ${ }^{50}$ In part because of the money, nationalist rhetoric and coercive measures the government

\footnotetext{
${ }^{48}$ Both within France and internationally, sheep have been consistently used as a symbol of the Larzac struggle since the earliest protests there in 1971. The sheep symbol used in this figure was digitally redrawn based on a design that appeared in numerous German pamphlets about the Larzac, including one promoting a 1977 talk by Larzac protester Hervé Ott in Bremen.

${ }^{49}$ Pierre-Yves de Boissieu interview.

${ }^{50}$ The Fast Breeder Reactor was promoted as a technology that would produce more energy in the form of plutonium than it consumed in uranium. The plutonium could then be used to power other nuclear reactors - or to build nuclear weapons.
} 
was willing to deploy in Malville, anti-nuclear activists found it difficult to establish the kind of unity among the affected population that Lanza del Vasto's intervention had helped achieve on the Larzac.

In their attempts to mobilise support, Malville activists associated themselves with the Larzac struggle, sought advice from the farmers there, and even brought Lanza del Vasto himself to protest in $1976 .^{51}$ After a surprisingly successful protest that year, Malville earned a reputation as the 'new Larzac', and a follow-up protest in 1977 was met with anticipation by protesters and police alike. ${ }^{52}$ Georges David, a neo-ruralist educator who had participated as a student in May 1968 in Paris, was a key regional organiser in Malville. According to him, the Larzac model was highly attractive, but ultimately failed in Malville because it was not suited to local conditions.

We had wanted in some sense to copy exactly the model of the Larzac onto Malville. That is to say, we very rightly thought that leadership... had to be from the local population. It was a very generous idea: 'It's normal that the people who are most concerned are in charge.' The problem was that... the population wasn't capable of providing that leadership... It had no past of struggle, no experience... It's a mistake to want to make a population provide leadership when it isn't ready to do so. ${ }^{53}$

The consequences of this 'mistake' were to prove fatal at the demonstration on 31 July 1977, when police responded to violent actions by a small minority of protesters (among a crowd of tens of thousands) with overwhelming and indiscriminate force. ${ }^{54}$ One protester, Vital Michalon, was killed and three individuals (including one policeman) sustained lifelong injuries from stun grenades exploding at close range. According to Georges David, the ultimate cause of the disaster was that the protest failed 'to mobilise enough people at the local level to counter-balance the force from outside', making it difficult 'to put the brakes on the passions of certain extremist elements. ${ }^{55}$ Large-scale, non-violent protest of the kind that had been so successful

\footnotetext{
${ }^{51}$ See, for example, 'Larzac-Malville' (1976), Private archives of Joseph Pineau, Millau.

${ }^{52}$ Note de service dated 30 March 1977 and 'Manifestation contre la centrale nucléaire...' report, Archives départementales (AD) de l'Isère, 6857 W 35 and W 36 (respectively).

${ }^{53}$ Interview with Georges David, conducted by AST, Lhuis, 27 Jan. 2010.

${ }^{54}$ Protest organisers spoke of 60,000 demonstrators, whereas police claimed only 20,000 had participated (of whom 300-400 were deemed to be violent). '60.000 sous la pluie', Super-Pholix 14 (undated) and Rapport du Colonel Roy (5 August 1977), AD Isère 6857 W 36.

55 Georges David interview.
} 
on the Larzac required a much higher degree of organisation than proved to be possible in Malville. ${ }^{56}$

Even if the Larzac model could not always be copied directly, its influence was nevertheless far-reaching. The plateau's networks of solidarity extended beyond France, across Europe and especially into neighbouring West Germany. Early supporters included German tourists who had taken notice of the struggle while passing through Southern France on holiday and politically conscious individuals who bought and sold Occitan wine and Lip watches. ${ }^{57}$ French leftists in the GOP successor Organisation communiste des travailleurs (OCT) spread news of the Larzac to their German sister organisation, the Hamburg-based Kommunistischer Bund, which dutifully promoted the struggle in its nationally distributed newspaper. Increasingly over the course of the 1970s, the Larzac gained supporters through its connections to the transnational anti-nuclear movement. In fact, the French ecologist paper La Gueule Ouverte (which temporarily fused with Combat Non-Violent in 1977) promoted a 'summer of struggles' in 1977 to bring French, German and other foreign protesters for a series of demonstrations from the Franco-German border in Alsace down to Malville, via Naussac and then to the Larzac. ${ }^{58}$ In a separate instance of 'social tourism', several hundred West Germans also travelled directly to the demonstration in Malville on 31 July 1977, many of them joining the Larzac rally two weeks later. ${ }^{59}$ The association forged between the Larzac and anti-nuclear protest brought in large numbers of allies from abroad, but these allies did not all understand the Larzac in the same way. Tensions developed between one network, which promoted the Larzac as a model of non-violent protest (as many Larzac farmers saw it), and another, for whom struggle against the state and military was more important (as many outside supporters in France felt).

\footnotetext{
${ }^{56}$ See also Andrew Tompkins, 'Transnationality as a Liability? The Anti-Nuclear Movement at Malville', Revue Belge de Philologie et d'Histoire, 89, 3-4 (2011), 1365-1380.

${ }^{57}$ Lothar Baier and David Wittenberg, 'LIP-Larzac', Ästhetik und Kommunikation 17 (1974), 43-44; Verein zur Förderung der deutsch-okzitanischen Freundschaft, 'Das Fass ist voll: Eine Region wehrt sich'; 'LIP-Info / Larzac-Rundbrief' (September 1982), Internationaal Instituut voor Sociale Geschiedenis (IISG), ZK 47369.

58 'Serpent des luttes, premier anneau: haguenau-la frontière allemande', La Gueule Ouverte 167 (21 July 1977), 2-3.

59 'Malville, Naussac, Larzac : Le tourisme social marque des points', La Gueule Ouverte 171 (18 August 1977), 1.
} 
The first network was the fruit of the friendship between Hervé Ott on the Larzac and Wolfgang Hertle in Hamburg. Hervé Ott's family was of Alsatian origin and he himself studied in Heidelberg in 1971-4. His Protestantism also gave him a privileged link to the German Lutheran church, which later sent volunteers via Aktion Sühnezeichen Friedendienste to perform their civil service on the Larzac. ${ }^{60}$ Wolfgang Hertle had grown up in post-war West Germany, where he became inspired at a young age by Gandhian civil disobedience. ${ }^{61}$ Disappointed by the traditional pacifist organizations that existed in the Federal Republic, he looked abroad for inspiration and founded the journal Graswurzelrevolution $(G W R)$ to share international news about non-violent direct action. A student of French and Political Science, he became an ardent supporter of the Larzac after reading about it in Témoignage Chrétien, a Christian left-wing magazine to which he subscribed from his home in Hamburg. GWR provided extensive Larzac coverage starting from its very first issue in 1972, and Hertle eventually wrote his doctoral thesis about the struggle. ${ }^{62}$ He visited the Larzac for the first time in 1973, and by the late 1970s had come to see protest there as a model for anti-nuclear protests closer to home, notably at the nuclear waste dump in Gorleben. In 1978, after Hervé Ott founded a research centre on peace and nonviolence at Le Cun on the Larzac, Hertle and his friends responded with a similar centre in Gorleben, the Kurve Wustrow. Hertle sent volunteers to Le Cun and invited Ott to speak at numerous events in Germany, while throughout the 1980s the two centres sponsored joint Franco-German meetings. ${ }^{63}$

The second network revolved around a separate group of anti-nuclear protesters from Hamburg associated with Heidi Burmeister and Volker Tonnätt. Their Larzac-Freundeskreis understood itself as 'non-non-violent', meaning not that they sought to undermine the strategy of the Larzac farmers, but that they, like many French gauchistes, read something different into the struggle. For them, the Larzac symbolised confronting the state (in the form of military and financial speculators) and preserving a rural way of life untarnished by consumerism. Burmeister and

\footnotetext{
${ }^{60}$ See the 'Rundbriefe vom Larzac' in Archiv Aktiv (AA), Hamburg, 'Le Cun du Larzac' folder.

${ }^{61}$ Interview with Wolfgang Hertle, recorded by AST, Hamburg, 22 July 2010.

62 'Antimilitarismus, Kritischer Konsum, Umweltschutz, Sozialismus, Dritte Welt', Graswurzelrevolution 0 (June 1972), 6 [http://www.graswurzel.net/0/larzac.shtml] (accessed 14 Nov 2012); W. Hertle, Larzac 1971-1981: Der Gewaltfreie Widerstand gegen die Erweiterung eines Truppenübungsplatzes in Süd-Frankreich (Kassel 1982).

${ }^{63}$ Ibid., 8. 'Rencontres franco-allemandes / Deutsch-französische Begegnungen', AA, Hamburg, 'Le Cun du Larzac' folder.
} 
Tonnätt produced flyers tailored to the concerns of the West German anti-nuclear movement, making much of recent discoveries of uranium deposits in Aveyron and describing Occitanie as a region threatened by 'the military, the tourist industry and nuclear power plants'. ${ }^{64}$ They promoted the Larzac struggle within Germany's leftwing scene too, getting articles about it published in the magazines links and id as well as the daily national tageszeitung. ${ }^{65}$ They also produced a book of interviews with Larzac farmers in German. ${ }^{66}$

Both of these networks created links between the Larzac and Gorleben that were in many ways mutually reinforcing. In March 1979, local farmers near Gorleben held a tractor procession to the state capital of Hanover in conscious imitation of the Larzac farmers' 1973 and 1978 marches to Paris. During summer vacations in 1979 and 1980, both German groups mobilized volunteers to help out with needed construction work on the Larzac. The bulletins of the Comités Larzac are full of praise for them, remarking that 'the integration of the Germans was excellent'; of 700 volunteers who spent 5-6 days each on the site in 1980, 'a good half came from Germany, where publicity was incontestably better done than in France. ${ }^{67}$ On the other hand, the non-violent and 'non-non-violent' activists represented factions of the anti-nuclear movement that competed with one another for influence in Germany, and both groups drew on their ties to the Larzac in order to build support for their respective positions. In September 1979 Burmeister and Tonnätt's left-wing Freundeskreis invited friends from the Larzac (Pierre-Yves de Boissieu and a member of the Millau Comité Larzac) to give a series of talks in Hamburg, Gorleben and elsewhere about protest on the plateau - shortly before Hervé Ott was scheduled to speak in Gorleben about non-violence. An associate of GWR who attended one talk complained to Gardarem lo Larzac that the left-wing speakers downplayed the importance of non-violence, thus misrepresenting the struggle to activists in Gorleben who might try to apply a similar model. Around the same time, Tonnätt wrote an open letter accusing non-violent activists of writing left-wing protesters out of the story in order to claim the Larzac as their victory alone. To drive the point home, he attacked the non-violent activists' plans for a training centre in Gorleben - by

\footnotetext{
64 'Okzitanien - bedroht von Militär, Touristikindustrie und Kernkraftwerken - mitten drinnen der Larzac', Private archives of Joseph Pineau.

${ }^{65}$ See, for example, 'Larzac 1979: „Auch in Zukunft als Bauer hier leben und arbeiten“', tageszeitung (24 Sept. 1979), 10.

${ }^{66} \mathrm{H}$. Burmeister and V. Tonnätt, Zu kämpfen allein schon ist richtig (Frankfurt 1981).

${ }^{67}$ Comités Larzac, bulletins of 8 and 20 Sept. 1980. Private archives of Joseph Pineau.
} 
savaging their Larzac-based model, Le Cun, as a waste of time and resources in the eyes of (some) plateau residents. ${ }^{68}$ Both the non-violent and 'non-non-violent' groups deployed the Larzac as a foreign example to shape protest locally, appealing to allies abroad to legitimate their claims. In doing so, they passed their own selective interpretations of the Larzac struggle on to wider audiences in West Germany that were less able to cross linguistic, cultural and national borders and therefore less attentive to the complexities of foreign protest.

Though the Larzac-Gorleben connection demonstrates that transnational protest had certain limits, those limits were not necessarily geographical: the Larzac's networks stretched beyond Europe, eventually reaching from Seattle to Tokyo and from Latin America to the Pacific. The publicity accorded to its struggle against militarism, imperialism and internal colonisation, and its ties to other anti-nuclear and ecological struggles attracted Third World activists and equally their supporters in immigrant communities in France.

At the rally in 1973 far-flung delegations were received from Chile, the Basque country and Palestine, each involved in their own liberation struggles. ${ }^{69}$ A year later, the farmers hosted another rally on the plateau, this time with a more consciously transnational message. Under the slogan 'Wheat feeds, weapons kill', the farmers drew attention to the use of the military base to test new weapons that would be used to put down liberation movements in the Third World. The grain ritually harvested that weekend was ceremonially given over to a Third World charity. ${ }^{70}$ The goal of the rally was to 'turn the Larzac, for these two days, into a privileged site of expression and of exchange for all the oppressed of the third world and of France'. ${ }^{71}$ Among those to attend were representatives of the African National Congress and the Mouvement des Travailleurs Arabes (MTA) which had been set up by North African immigrant workers in France, inspired by the Palestinian struggle. Groups like these appreciated the tribune that the Larzac rally gave them, saying that 'never before has such a large possibility of expression been offered' and considering it 'a step forward' towards the goal of achieving unity among French people and immigrants. ${ }^{72}$ For their

\footnotetext{
${ }^{68}$ Press clippings and correspondence in 'Larzac en RFA' folder, Private archives of Joseph Pineau, including 'Le Cun du Larzac - kein ermutigendes Beispiel!', id 303 (12 Oct. 1979).

${ }^{69}$ Rawlinson, Larzac, 81.

${ }^{70}$ Pauline Vuarin, 'Larzac 1971-1981', 68.

71 'Larzac-Informations, Spécial Tiers Monde', AD de l'Aveyron, Rodez, 747 W 6.

${ }^{72}$ Report by the Comités unitaires français-immigrés in Comité parisien de soutien aux paysans du Larzac, 'Larzac - la lutte continue' (brochure), Paris, BnF, recueil « Larzac », 24-25.
} 
part, the farmers deemed that this second rally, even more than the previous one (LipLarzac), had 'permitted us to get to know the ideas and motivations of those that support us' ${ }^{73}$

In 1981 François Mitterrand became president and promptly cancelled plans to extend the military camp. ${ }^{74}$ After their success the Larzac farmers and activists returned the solidarity that had been shown towards them by supporting the struggles of others in the developing world against militarism, colonialism and multi-national capitalism, advocating the practice of non-violent resistance that they had learned from Gandhi's disciple Lanza del Vasto and had adapted for their own cause. In 1982 a Larzac Foundation was set up to 'undertake research on alternatives to the dominant model of development both on the plateau and outside, notably in the Third World' ${ }^{75}$ Christiane and Pierre Burguière explain:

CB: The Larzac was bound to return the solidarity it had received in support. We had to pay back that solidarity where we were asked to, whether in local struggles or international ones, like -

PB: The Kanaks, the Tahitians -

CB: Japan...

PB: We feel that we have changed in many ways. We are more open to the problems of the world, and more rebellious too, as there are things that we cannot tolerate.

CB: We have remained aware of everything that happens, everything of concern, in fact of everything that is unjust. ${ }^{76}$

The Larzac became an inspirational model to other communities facing the brutal power of the state, whether Japanese peasants opposing the extension of Narita airport near Tokyo or the Kanak community of New Caledonia. The basic, Rousseauesque narrative of simple and virtuous peasants struggling peacefully for their land had a mythic quality. Yet these were far from simple peasants. The Burguières and Tarliers were at the forefront of new farming methods and had important connections to powerful farmers' leaders such as Bernard Lambert. They had learned about non-violence at the feet of charismatic leaders such as Lanza del Vasto, who traced his heritage back to Gandhi, and later from General Jacques de

\footnotetext{
${ }^{73}$ Ibid., 9-10.

${ }^{74}$ Some speculated that Mitterrand's decision was in part motivated by gratitude for the protection the Larzac farmers gave him when he was attacked by leftists while attending the 1974 rally.

${ }^{75}$ Pierre-Marie Terral, Larzac. De la Lutte paysanne à l'altermondialisme (Toulouse, Privat, 2011), 228-9.

${ }^{76}$ Pierre and Christiane Burguière interview.
} 
Bollardière, who had resigned from the army over the use of torture in Algeria and became a campaigner for non-violence. ${ }^{77}$ The success of 'peasant' protest depended on cooperation with urban gauchistes and neo-ruralist hippies who were now thinking about the role of the local and decentralised in the strategy of revolution. The likes of Pierre Vuarin and Hervé Ott were intellectuals as well as activists. European and Third World activists made pilgrimages to the plateau and some who settled were citizens of the world: José Bové had himself spent his childhood in California and spoke fluent English. For ten years the Larzac was a laboratory where insiders and outsiders together thought about law and justice, politics and the media in order to widen support for their cause.

That said, there were problems with the transnational outreach of the Larzac. As in Malville and West Germany, the Larzac model of non-violence encountered difficulties and contradictions. In France's last colony, New Caledonia, Kanak freedom fighters had founded the Front de Libération Nationale Kanak et Socialiste (FLNKS) to struggle for land and independence against France and the French settler colony known as Caldoches. After a failed insurrection in 1984 Kanak leaders JeanMarie Tjibaou and Yéwéné Yéwéné came to the Larzac to meet those who had successfully campaigned against being driven off their land. Tjibaou was a former priest and his Catholic past and the common struggle to defend ancestral land brought the two worlds together. The Larzac lawyer François Roux was key to building bridges. Guy and Marizette Tarlier visited New Caledonia in 1987 and Hervé Ott went several times to advise the Kanaks on non-violent strategies such as road-blocks and sit-ins; pictures of white police clubbing sitting Kanaks had powerful media impact. $^{78}$

The message of non-violence was shattered in May 1988, during the French presidential elections, when Kanak militants took a number of gendarmes hostage in May 1988, campaign, and held them in the Ouvea caves. The Chirac government sent in a commando force to free them and twenty-one Kanaks were killed. Tjibaou and Yéwéné Yéwéné subsequently agreed to a compromise negotiated later in 1988 by Chirac's successor as prime minister, Michel Rocard, but they paid the price for this

\footnotetext{
${ }^{77}$ Général de la Bollardière, Bataille d'Alger, bataille de l'homme (Paris, Éditions Desclée de Brouwer,1972); Jean Toulat, Combattants de la non-violence. De Lanza del Vasto au Général de la Bollardière (Paris, Cerf, 1983)

${ }^{78}$ Hervé Ott, De la non-violence à l'approche et transformation constructives des conflits, Conflits, Cultures, Coopérations Cahier no. 6 (March, 2007), 23-5 ; Terral, Larzac, 231
} 
compromise, assassinated in 1989 by an angry Kanak militant, who was then shot dead by a gendarme. In this difficult reality, the non-violent strategy failed, but symbolically the message lived on in a dramatic act of reconciliation. The Larzac community set aside a plot of land on the plateau which they gave to the Kanaks and sanctified with a shrine. In 2005 it became the site of a ceremony of forgiveness and reconciliation between the widows of Tjibaou and Yéwéné Yéwéné and that of the Kanak who killed them. It typified the transformative effect of the Larzac struggle, opening up the plateau to an understanding of global struggles but also pouring the balm of Christian generosity and an ethic of non-violence on troubled peoples far away. Christiane and Pierre Burguière reflect:

CB: Marie-Claude Tjibaou was a woman of the world, you could see that she had lived and travelled.... She and the wife of Yéwéné were the wives of chiefs, whereas the wife of the assassin was just a village woman... She spoke the last, her head bowed. She found it hard to raise her head -

PB: To look at us -

CB: Finally, when she spoke, a ray of sunlight illuminated her face.

PB: We were 300 or 400 people -

$\mathrm{CB}$ : And everyone was crying. ${ }^{79}$

At the end of the 1990s a new generation of Larzac activists took the message of the plateau to a much wider range of global struggles: opposition to France's resumption of nuclear testing, the defence of landless Latin American peasants expropriated by American multinationals and support for Palestinian refugees. Several of the new campaigns were led by José Bové, who had occupied Montredon farm on the Larzac in 1976, and who saw himself as the heir of Bernard Lambert. ${ }^{80}$ Bové used his authentic rural platform on the Larzac to launch transnational protest against threats of globalisation worldwide, but equally he used the global profile he obtained to campaign locally against genetically modified organisms (GMOs) and the World Trade Organisation (WTO) - and to campaign personally for the French presidency and a seat in the European Parliament. When the Chirac government resumed nuclear weapons testing in the Pacific in September 1995, José Bové and Christian Rocqueirol took part in the Greenpeace protest on board the Rainbow Warrior in Moruroa atoll with T-shirts declaring 'Larzac - no to testing!' and made common cause with Polynesian independence campaigners. In 1998 Bové was in Brazil as

\footnotetext{
${ }^{79}$ Pierre and Christiane Burguière interview.

${ }^{80}$ From 2000 to 2004, Bové even served as speaker of the Confédération Paysanne, a peasants' trade union set up in 1987 as the successor to Lambert's Paysans-Travailleurs.
} 
leader of the Confédération Paysanne, linking up with the Vía Campesina movement to support the campaign of landless peasants to occupy uncultivated land. ${ }^{81} \mathrm{He}$ also declared his support for the Indians of the Chiapas region of Mexico fighting in the Zapatista National Liberation Army under Subcomandante Marcos, a former university-teacher-turned-guerrilla. ${ }^{82}$ In some ways Bové represented the Larzac as a whole on the global stage.

Battles against globalisation were not always fought in far-flung parts of the world; they could be undertaken at the local level, in everyday life. The maxim 'think globally, act locally' illustrated the concept of glocalism which held the global and the local in creative tension; at numerous protests, Bové and his associates have used local action to challenge what they regard as global problems. He was turned into an international star as a result of a sensational 1999 protest where he and other members of the Confédération Paysanne 'dismantled' a McDonald's restaurant in Millau, the small town nearest the Larzac. The protest was justified as a defence of the Roquefort cheese that his sheep produced, which had recently become collateral damage in a trade war after the US imposed WTO-endorsed sanctions against quality goods in retaliation for a French ban on hormone-treated beef. The glocal gesture of defending Roquefort cheese - 'the most local product possible and the most symbolic of local products' - against corporate, mass-produced malbouffe ('junk food') hit a nerve. ${ }^{83}$ When Bové was subsequently arrested for the McDonald's protest, photographs of the mustachioed Frenchman proudly holding his handcuffed hands above his head circulated throughout the world, inspiring comparisons with real and imagined Gallic heroes from Vercingétorix to Astérix. ${ }^{84}$ Bové achieved a further media coup later that year by travelling to Seattle to join anti-WTO protests - and smuggling in 200 kilos of Roquefort cheese with his entourage. He consolidated his international fame again in 2001 by destroying genetically modified crops while in Porto Alegre, Brazil to attend the first World Social Forum. ${ }^{85}$

The global and the local were perhaps most clearly brought together during José Bové's trial over the McDonald's affair in 2000, when allies from around the world

\footnotetext{
${ }^{81}$ See, for example, J. Bové, ‘A Farmer's International?', New Left Review 12 (Nov./Dec. 2001).

${ }^{82}$ Terral, Larzac, 295-6, note 237.

${ }^{83}$ José Bové, quoted in G. Williams, Struggles for an Alternative Globalization. An Ethnography of Counterpower in Southern France (Hampshire, Ashgate, 2008), 1.

${ }^{84}$ Ariès and Terras, José Bové. 25, 36-9, 47-79; José Bové and François Dufour, Le Monde n'est pas une marchandise (Paris, La Découverte, 2000), 15-21, 79.

${ }^{85}$ Williams, Struggles for an Alternative Globalization, 4-5.
} 
reciprocated solidarity with Bové and with the Larzac. Witnesses came from all the global hotspots - Hirohiti Tefaarere from Tahiti, the Honduran Rafael Alegria for Vía Campesina, Bill Christison from the National Family Farm Coalition in the USA - to testify in favour of Bové. ${ }^{86}$ Red priest Jacques Guillot, dismissed from his bishopric at Evreux, highlighted the transnational dimension: 'We are seeing a universalisation of resistance in South America, Africa, Asia and representatives from those countries and of all who are suffering from globalisation are here today in Millau, where there is an old tradition of struggle'. ${ }^{87}$

The Larzac established itself as a glocal mainspring and showcase of transnational struggles. This was consecrated by a rally held in 2003 on the plateau, commemorating the thirtieth anniversary of the first great rally in 1973. Under slogans such as 'Construire un monde solidaire' and 'Le monde n'est pas une marchandise', 300,000 came to the Larzac on 9 August 2003, including the indigenous peasant leader (and future Bolivian president) Evo Morales, the activist American lawyer Lori Wallach, and the Indian anti-GMO campaigner Vandana Shiva alongside well-known French protesters such as Gustave Massiah (CRID) and Jacques Nikonoff (ATTAC). ${ }^{88}$ This openness to outsiders near and far, however, in no way diminished attachment to the local. Christiane and Pierre Burguière highlighted the place the Larzac had achieved over the years both in local and in global consciousness:

CB: When we commemorated the thirty years of the Larzac struggle, or rather the rally of 1973, we commemorated it with another rally, that of 2003 against GMOs. There were 300,000 people on the Larzac.

PB: We saw lots of people from the old Larzac committees whom we hadn't seen since.

CB: Some of whom we didn't even recognise.

RG: Had they cut their hair?

$\mathrm{CB}$ : They had put on weight.

PB: It showed the impact that the Larzac has had on opinion, and not only in France. For many people it has become a point of reference. ${ }^{89}$

Whatever has happened to Larzac activists since 1981, the plateau itself remains marked by the solidarity it received: former activists from all over have turned it into a popular site for ecological tourism. In 2011, the Larzac was deemed to be at the

\footnotetext{
${ }^{86}$ Terral, Larzac, 247.

${ }^{87}$ La Dépêche du Midi, 1 July 2000, cited by Terral, Larzac, 261

88 'Présentation des forums'(2003) [http://www.monde-solidaire.org/larzac-2003/intervenants.htm] (accessed 1 July 2013).

89 Pierre and Christiane Burguière interview
} 
heart of the UNESCO World Heritage site in the Causses and Cévennes, regarded as a prime example of the Mediterranean pastoral economy. Pierre-Yves de Boissieu, who continues to live and work on the plateau, does not like to think of how things might have gone if the military had gotten its way:

'When they decided to do the military camp, it was predicted that there would be 2,000 jobs. Well, first of all, there would never really have been 2,000 jobs. But they didn't see that they would have sacrificed a region. Let's imagine that the military camp had been done: I mean, that would place an enormous lock on this region - which has developed in a completely different direction today... The Parc Régional des Grands Causses has been created, plenty of open-air activities, stuff like that. And we would have had that thing in the middle of the Larzac. And we [would] learn twenty years later that it's no longer necessary, that they're going to close it. So I think the struggle that was fought was entirely justified. ${ }^{90}$

\section{Conclusion}

The Larzac is a case of a highly local struggle that became deeply enmeshed in global protest. Its success may be explained by a combination of the mythic power of the idea of peasants fighting for their way of life against a militaristic state, the range of networks on which they were able to draw - whether local, regional, or transnational - and the sophisticated learning process they underwent in what became a ten-year experiment in non-violent protest. Their example inspired other activists fighting similar battles in defence of land and livelihood in other parts of the world, from Latin America to the Pacific.

There were nevertheless limits to application of the Larzac model. The message was reinterpreted in different ways in different contexts. What was most important on the plateau was not always what was most important about the plateau for outside supporters. In some places, such as Malville, activists did not enjoy enough support from the local population to ensure that mass protest remained non-violent. West German activists were divided about what the Larzac meant and what they should take from it for their own protests in Gorleben. In the Third World activists were often locked into extremely violent struggles with colonial-type settlers, brutal regimes, multi-national companies and American imperialism where the non-violent model was difficult to graft. While the farmers and activists of the Larzac could support other struggles and offer advice to their protagonists, they could not direct

\footnotetext{
${ }^{90}$ Pierre-Yves de Boissieu interview.
} 
them or control the conditions under which their allies operated. That said, the Larzac farmers formed bonds of mutual solidarity with people in all these places, reaping considerable benefits for their own struggle and sharing those benefits as best they could.

The Larzac was also a site that encapsulated the tension between local and global in the glocal. Contact with the wider world made local farmers and activists into cosmopolitans, as the cases of Guy Tarlier, Hervé Ott and José Bové demonstrate. The Larzac became a mainspring of global activism and solidarity. It was also a showcase that demonstrated that global battles could also be fought locally, as epitomised by the dismantling of the McDonald's in Millau, which mobilised historic, local identities in a fight against global consumerism. Global celebrities were brought in to the locality for Bové's trial in 2000 and for the 30th anniversary celebrations in 2003. The Larzac could not retain its activist energy indefinitely and perhaps it became more of a glocal showcase than mainspring, a lieu de mémoire of transnational protest. Or perhaps, as a UNESCO site, it reverted to the place of natural beauty that the sheep farmers were seeking in the first place to preserve. 